研究課題別評価

1. 研究課題名：「半導体における非共鳴非捸動非線形光学効果」

2. 研究者氏名：河野 淳一郎

3. 研究のねらい :

本研究の目的は、中赤外・遠赤外 (またはテラヘルツ) 強電場下に置かれた半導体の光学的 性質を調べることである。強電場中のブロッホ粒子の運動、また谷れによる系の光学的性質の 変化を理解することは固体物理学における中心課題の一つである。強電場に摇すられた電子、 正孔、励起子のダイナミクスは半導体バンド端近傍の光学的性質に劇的な影響を与える。例え ば、よく知られたフランツ・ケルディッシュ効果や量子閉じ込めシュタルク効果においては、強電 場はバンド端以下での吸収を引き起こし、励起子共鳴線を大きく動かす。このような電気光学効 果は基礎・応用両面において興味を持たれ、バルクおよび種々の量子閉じ込め半導体構造にお いて幅広く研究されてきた。

4. 研究結果及び自己評価 :

私のさきがけ研究における最大の結果は、強電場の周波数を徐々に上げていくときに電気光 学効果がどう変化していくかに一つの明暸な答えを与えた点である。交流電場中の量子系は振 動数と電場強度の相対比によって非常に異なった振る舞いをすることか知られている。非共鳴 現象に話を限杖、これらの振る舞いは動重エネルギー (運動エネルギーの時間平均) とフォ卜 ンエネルギーの比によって古典領域と量子領域に分類される。我々は半導体中でこの両者かぼ ぼ同樣に重要になる領域において異常に大きな超高速電気光学効果の観測に成功した。バド 端以下約1電子ボルトにまでおよぶこの巨大誘導吸収は、30年以上前に理論的に予言されたダ イナミック・フランツ・ケルディッシュ効果としてうまく説明できる (16)。

図 1 にaAsにおける典型的なデータを示す。中赤外強電場での超短パルスが存在する瞬間 のみに巨大誘導吸収が起きることが見える。

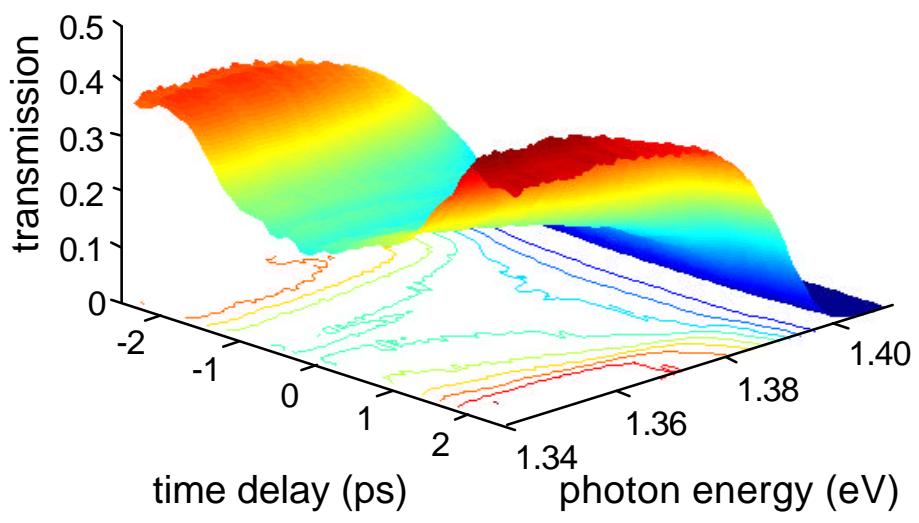

上記の巨大誘導吸収に加え、樣々な多光子非線型過程を中・遠赤外領域て調べたロ小さなフ オトンエネルギーは帯間吸収を最小化することによって試料破壊を防ぐ。また、長波長領域に存 
在する小さな分散は長い位相整合距離を可能にする。さらに、動重ポテンシャルはフォトンエネ ルギーと同程度までに増大する。これらの利点を最大限に利用して哦々は最大 7 光子まで含む 過程の観測に成功した。サイドバンド発生プロセスにおいては、微弱な可視光線がテラヘルツ電 場に摇すられた半導体を透過する際にテラヘルツ周波数の整数倍だけ離れたサイドバンド周波 数を取得する (図 2 参照)。

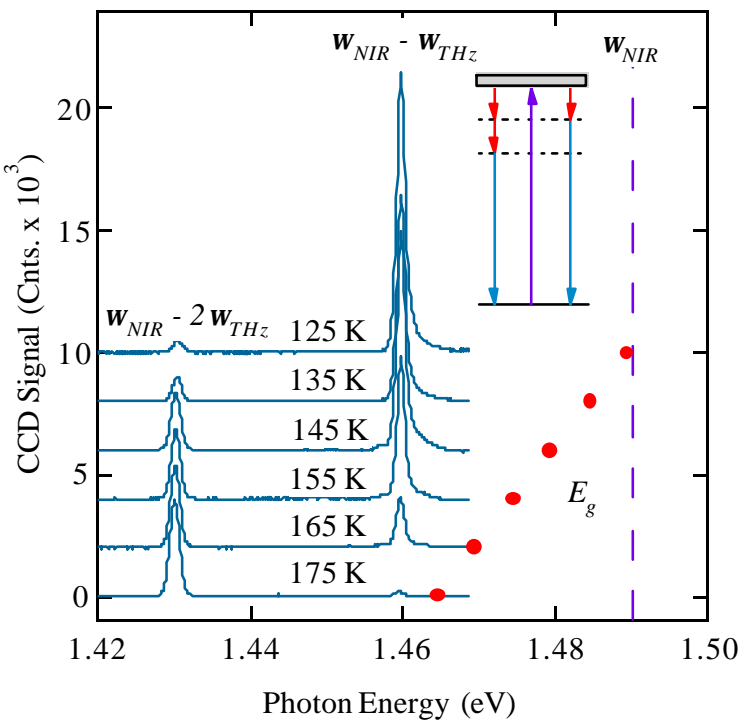

我々はテラヘルツ電場にドライブされた半導体のバンド端近傍の光学的性質はこれらのサイド バンド光に圧倒的に支配されることを示したロ

このような研究は、非平衡多電子系の非線型ダイナミクスに対して全く新しい知見を与えると 共に、技術的に未開の地である中・遠赤外領域で作動する半導体デバイスの開発につながると 考えられる。特に、上記の樣々な結果を利用した超高速スイッチング・超高速電気光学変調の実 現は、光通信・光コンピュータの分野への応用が期待される。

5. 領域総括の見解 :

本研究者は、本研究領域では例外的に在米研究者である。しかしながら、申請の研究内容が 本研究領域の状態と変革ととう共通のテーマに密接に関連する野心的なものであることロ 国 内ではまだ実用化が立ち遅れている自由電子レーザーを駆使して、光と電波の中間の未開拓 領域である中遠赤外〜テラへルツ電磁波が半導体に及ぼす強電場効果を実験的に解明しよう とする意欲的な目標力評価されて第 2 期研究者として採択された。产の後 3 年間の研究成果 は口十分にこの期待に応える極めて高い水準のものであり口基礎的物性研究としてだけでなく、 超高速光变調素子など将来の新規技術の開拓に新しい可能性を開拓したものと言える。

研究期間の終盤に所属大学を变更したが講師から助教授への昇格によって研究環境の改 善により大きな自由度がもたらされ、本研究課題の実施にとってより良い有利な状況下で研究 か継続された。本領域研究会議での研究者間の交流に積極的に貢献したこともロ特筆に価す る。 


\section{6. 主な論文等}

賞 :

1) National Science Foundation, CAREER Award, 2001.

\section{招待論文・解説記事 :}

1) J. Kono, " Cyclotron resonance," in Methods in Materials Research, edited by E. N. Kaufmann, R. Abbaschian, A. Bocarsly, C.- L. Chien, D. Dollimore, B. Doyle, A. Goldman, R. Gronsky, S. Pearton, and J. Sanchez (J ohn Wiley \& Sons, New York, 2001), Unit 9b.2.

2) J. Kono and A. H. Chin, " Extreme midinfrared nonlinear optics in semiconductors" (invited paper), to be published in the Proceedings of the $26^{\text {th }}$ International Conference on Infrared and Millimeter Waves.

3) J.Kono and A. H. Chin, " Extreme nonlinear optics in semiconductors with small energy photons" (invited paper), to be published in the Proceedings of the $10^{\text {th }}$ International Conference on Narrow Gap Semiconductors and Related Small Energy Phenomena, Physics and Applications, J pn. J . Appl. Phys., Suppl.

4) T. Inoshita, J. Kono, and H. Sakaki, “ Resonant terahertz sideband generation in quantum wells and exciton spectroscopy," 日本物理学会誌 53, 700 (1998).

5) J. Kono, M. Y. Su, J. Cerne, M. S. Sherwin, S. J . Allen, J r., T. Inoshita, T. Noda, and H. Sakaki, " Resonant generation of terahertz optical sidebands from confined magnetoexcitons" (invited paper), Nuclear Instruments and Methods in Physics Research B 144 (1998), pp. 115- 122.

6) J. Kono and T. Inoshita, " Terahertz spectroscopy of excitons with free- electron lasers," 固体物理 32 (1998), pp. 617624.

\section{発表論文・会議プロシーディング :}

7) M. A. Zudov, J. Kono, A. P. Mitchell, and A. H. Chin, " Time- resolved, nonperturbative, and off- resonance generation of optical terahertz sidebands from bulk GaAs," Physical Review B - Rapid Communications 64 (2001), 121204(R).

8) A. H. Chin, O.G. Calder n, and J. Kono, " Extreme mind nfrared nonli near opti csi n semiconductors," Physical Review Letters 86 (2001), pp 3292- 3295.

9) O.G.Calder n, A. H. Chin, and J.Kono, " Mitiphoton processes inthe presence of self- phase modulation," Physical Review A 63 (2001), 053807 (9 pages).

10) Y. H. Matsuda, T. Ikaida, N. Miura, M. A. Zudov, J. Kono, and H. Munekata, " Electron cyclotron resonance in $\operatorname{In}_{1-x} \mathrm{Mn}_{x} A$ s," Physica E 10 (2001), pp. 219- 223. 
11) M. A. Zudov, A. P. Mitchell, A. H. Chin, J . Ko n o, and K. J ohnsen, " Non- perturbative terahertz sideband generation from bulk GaAs," Proceedings of the $25^{\text {th }}$ International Conference on the Physics of Semiconductors, edited by N. Miura and T. Ando (Springer- Verlag, Berlin, 2001), pp. 77- 78.

12) M. A. Zudov, J. Kono, T. Ikaida, Y. H. Matsuda, N. Miura, S. Sasa, and M. Inoue, " Cyclotron resonance anomalies near the semimetal- semiconductor transition in a $2 \mathrm{D}$ electron- hole system," Proceedings of the $25^{\text {th }}$ International Conference on the Physics of Semiconductors, edited by N. Miura and T. Ando (Springer- Verlag, Berlin, 2001), pp. 991- 992.

13) J. Kono and A. H. Chin, " Ultrafast electro- absorption at the transition between classical and quantum response," Proceedings of the $25^{\text {th }}$ International Conference on the Physics of Semiconductors, edited by N. Miura and T. Ando (Springer- Verlag, Berlin, 2001), pp. 188- 189.

14) J. Kono, A. H. Chin, and O. G. Calder n, " Extreme inimfrared nonlinear optics in semiconductors," Proceedings of the $25^{\text {th }}$ International Conference on the Physics of Semiconductors, edited by N. Miura and T. Ando (Springer- Verlag, Berlin, 2001), pp. 583584.

15) A. H. Chin and J. Kono, " Ultrafast electro- absorption at the transition between classical and quantum response," UItrafast Phenomena XII, edited by T. Elsaesser, S. Mukamel, M. M. Murnane, and N. F. Scherer (Springer Verlag, Berlin, 2001), p. 360.

16) A. H. Chin, J . M. Bakker, and J . Kono, “ Ultrafast electro- absorption in semiconductors at the transition between classical and quantum response," Physical Review Letters 85 (2000), pp 3293-3296.

17) A. P. Mitchell, A. H. Chin, and J. Kono, " Picosecond time- resolved cyclotron resonance of non- equilibrium carriers in semiconductors," Physica B 272 (1999), pp. 434437.

18) J. Kono, A. H. Chin, A. P. Mitchell, T. Takahashi, and H. Akiyama, " Picosecond time- resolved cyclotron resonance in semiconductors," Applied Physics Letters 75 (1999), pp. 1119- 1121. 